\title{
Allometry of the skull in one autochthonous and two reintroduced populations of Eurasian beavers (Castor fiber, Castoridae, Rodentia)
}

\begin{abstract}
Andrey Yu. Puzachenko \& Nikolay P. Korablev
ABSTRACT. Allometry is a common phenomenon that is found in animals at different levels: between sexes, species, and higher taxonomic levels. For example, an 'allometric mechanism' of regulation shows variation at the population level and therefore it is the source of morphological diversity at the species level, and additionally, the allometric relationship is influenced by natural selection. To better understand the constraints of ontogenetic and static allometry, we investigated 493 skulls (15 measurements per skull) from three geographically isolated populations of Eurasian beaver (populations of Voronezh Reserve, Oka Reserve, and Central Forest Reserve), all belonging to the Eastern European subspecies Castor fiber orientoeuropaeus. The allometric growth in terms of the general length of the beaver skull depends on the specific growth of its rostral part (nasal bone, intermaxillae, and diastema) in all studded populations. The pattern of static allometry in adult animals was mostly similar to the pattern of ontogenetic allometry, but in adults, isometry was predominated. The PCA results showed clear differences in the ontogenetic allometric patterns of different populations. All these results confirm our preliminary hypothesis (Puzachenko \& Korablev, 2014) about the influence of ontogenetic allometry on the skull parameters in these beaver's populations.
\end{abstract}

KEY WORDS: ontogenetic allometry, static allometry, Castor fiber, skull morphology.

Andrey Yu. Puzachenko [puzak1@rambler.ru], Institute of Geography, RAS, Staromonetnyi per. 29, Moscow 109017, Russia; Nikolay P. Korablev [cranlab@gmail.com], Velikie Luki State Agricultural Academy, Velikie Luki, Pskov oblast 182112, Russia, Pskov State University, Pskov 180000, Russia

\section{Аллометрия в черепе евразийских бобров (Castor fiber, Castoridae, Rodentia) из одной автохтонной и двух реинтродуцированных популяций}

\section{А.Ю. Пузаченко, Н.П. Кораблев}

РЕЗЮМЕ. Аллометрия является распространенным явлением и встречается у животных разных полов, видов и на более высоких таксономических уровнях. Аллометрическая изменчивость, например, на уровне популяций, является источником морфологического разнообразия на видовом уровне и может быть объектом естественного отбора. Онтогенетическую и статическую аллометрию исследовали по 15 промерам на 493 черепах евразийских бобров восточноевропейского подвида (Castor fiber orientoeuropaeus) из трех географически изолированных популяций (Воронежский заповедник, Окский заповедник и Центрально-Лесной заповедник). В постнатальном онтогенезе аллометрия возникает, прежде всего, из-за неравномерных скоростей роста церебрального и рострального отделов черепа. Аллометрический паттерн у взрослых животных в основном аналогичен паттерну онтогенетической аллометрии, но с доминированием изометрии. Обнаружены четкие различия между разными популяциями бобров по параметрам онтогенетической аллометрии. Результаты подтверждают нашу гипотезу (Пузаченко, Кораблев, 2014) о влиянии онтогенетической аллометрии на морфологическую изменчивость черепа бобров из разных популяций.

КЛЮЧЕВЫЕ СЛОВА: онтогенетическая алЛометрия, статическая аллометрия, Castor fiber, морфология черепа. 


\section{Introduction}

The mammalian skull is considered as a highly specialized multifunctional complex skeletal system in which the relationships among its parts (skull subsystems) undergo limited change (Romer \& Parson, 1985; Trainor et al., 2003; Klingenberg et al., 2004; Klingenberg, 2014). This limits its potential morphological diversity. Integrated phenotypes are the result of interactions among their morphological elements due to genetic and epigenetic (functional and developmental) relationships between them, as expressed during the course of individual development (Olson \& Miller, 1958; Cheverud, 1996; Klingenberg \& Zimmermann, 1992). According to Klingenberg (1996), static allometry (size allometry) reflects variation among individuals within homogeneous age groups at the population level. Ontogenetic allometry (growth allometry) is the consequence of covariation among traits during growth. Both types of allometry can be used for various comparisons across different populations of the same species that have different histories, live in different environments, and are subjected to different environmental constraints.

To better understand the allometry patterns in the autochthonous and reintroduced populations of Eurasian beavers, we investigated ontogenetic and static allometry from skulls from three geographically isolated populations, all traditionally listed in the Eastern European subspecies Castor fiber orientoeuropaeus Lavrov, 1981. All studied populations are genetically close and belonging to the Eastern mitochondrial haplotypes clade (Horn et al., 2014; Senn et al., 2014).

Variations in quantitative and qualitative traits of the skulls of beavers from many reintroduced and autochthonic populations have already been described (Korablev et al., 2011, 2015; Korablev \& Korablev,
2013). Preliminary comparisons of the Voronezh autochthonous population (VO); Oka reintroduced population $(\mathrm{OK})$; and Central Forest reintroduced population (CF) studied in our work (Puzachenko \& Korablev, 2014) have indicated that the ontogenetic growth of the skull in each population has specific properties that affect the size and shape of the skull in different age classes of animals.

\section{Materials and methods}

Samples (493 beaver skulls) were collected from three geographically isolated populations from the Voronezh, Tver', and Ryazan provinces (in European part of Russia) (Table 1). The material is held at the Voronezh State Nature Biosphere Reserve, Central Forest State Nature Biosphere Reserve, and Zoological Museum of Moscow State University.

The histories of the reintroduced populations are well documented: we know their starting points and have had the opportunity to investigate the morphological changes that have occurred in the beavers in their new environments. From 1936 to 1937 , beavers were imported in two groups from the Voronezh State Nature Biosphere Reserve population. The first group was introduced to the core of the Central Forest State Nature Biosphere Reserve along the Tyud'ma River (Volga River basin). After the deaths of several beavers, approximately eight individuals established the CF population (the more detailed information is not available). Since the 1980s, the long-term average population size has been about 200 beavers. The other group of beavers was reacclimatized in the Oka State Nature Biosphere Reserve (Pra River, Oka River basin) starting in 1937, and over the subsequent 3 years, 30 beavers were released. Overall, seven animals died; the remaining 23 beavers established the OK population.

Table 1. Sample sizes of skulls of the Eurasian beaver and characteristics of geographical locations of the studied populations.

\begin{tabular}{|c|c|c|c|c|c|c|c|c|}
\hline \multirow[b]{2}{*}{$\begin{array}{l}\text { Sample } \\
\text { code }\end{array}$} & \multirow[b]{2}{*}{ Geographic locality } & \multirow[b]{2}{*}{ Total } & \multicolumn{3}{|c|}{ Males } & \multicolumn{3}{|c|}{ Females } \\
\hline & & & $\begin{array}{l}\text { jv1- } \\
\text { jv2 }\end{array}$ & sad & $\begin{array}{c}\text { ad1- } \\
\text { ad4 }\end{array}$ & $\begin{array}{c}\text { jv1- } \\
\text { jv2 }\end{array}$ & sad & $\begin{array}{l}\text { ad1- } \\
\text { ad4 }\end{array}$ \\
\hline VO & $\begin{array}{l}\text { Voronezh Province, Voronezh State } \\
\text { Nature Biosphere Reserve, Voronezh } \\
\text { River basin, } 52^{\circ} 06^{\prime} \mathrm{N}, 39^{\circ} 26^{\prime} \mathrm{E} . \\
\text { Autochthonous / aboriginal } \\
\text { population. }\end{array}$ & 84 & 11 & 6 & 30 & 10 & 3 & 24 \\
\hline OK & $\begin{array}{l}\text { Ryazan Province, Oka State Nature } \\
\text { Biosphere Reserve, Pra River basin, } \\
54^{\circ} 45^{\prime} \mathrm{N}, 40^{\circ} 45^{\prime} \text { E. Reintroduced } \\
\text { population. }\end{array}$ & 255 & 10 & 17 & 91 & 16 & 27 & 94 \\
\hline $\mathrm{CF}$ & $\begin{array}{l}\text { Tver' Province, Central Forest State } \\
\text { Nature Biosphere Reserve, Volga } \\
\text { River and West Dvina watershed } \\
\text { (Daugava) River, } 56^{\circ} 30^{\prime} \mathrm{N}, 32^{\circ} 55^{\prime} \\
\text { E. Reintroduced population. }\end{array}$ & 154 & 46 & 19 & 32 & 27 & 14 & 16 \\
\hline
\end{tabular}


The age classes of the beavers were determined based on the degree of closure of the basal opening of the pulp cavity of molars, and the layered structure of cement in the apical part of the tooth in animals older than 3 years old (Safonov, 1966; Klevezal, 1988). Seven age classes were distinguished: 6 months to 1 year old (jv1), 1 to 2 years old (jv2), 2 to 3 years old (sad), 3 to 4 years old ( $\operatorname{ad} 1), 4$ to 5 years old $(\mathrm{ad} 2), 5$ to 7 years old $(\operatorname{ad} 3)$, and $>7$ years old (ad4). Sexual dimorphism has an insignificant effect on the morphological characteristics of the skulls of Eurasian beaver skull (Lavrov, 1981; Kitchener \& Lynch, 2000; Puzachenko \& Korablev, 2014; Korablev et al., 2015). There was no sexual dimorphism in any later age classes. Therefore, in the present study, we ignored the effects of gender.

Measurements: 1 - greatest length of skull (GL), 2 - length of rostral part of skull (right side) (RL), 3 nasal length (right side) (NL), 4 - alveolar length of upper molar toothrow (right side) (UML), 5 - length of upper diastema (UDL), 6 - width of upper jaw or width of the rostrum (UJW), 7 - interorbital width (IOW), 8- zygomatic width (ZW), 9 - cranial width (CW), 10 - mastoid width (MW), 11 - length of upper jaw - from the posterior part of the articular surface of the zygomatic bone to the front edge of the incisor bone (right side) (UJL), 12 - alveolar length of lover toothrow (right side) (DML), 13 - length of mandible (right side) (ML), 14 - greatest length of mandible - from the posterior edge of the articular process to the most outstanding front edge of the alveolus of incisor (right side) (GML), 15 - height of mandible (right side) $(\mathrm{MH})$.

Ontogenetic and static multivariate allometry. We used multivariate allometry coefficients (MACs) to compare the three populations. A principal component analysis (PCA) of the variance-covariance matrix of natural log-transformed skull measurements according to previous studies (Jolicoeur, 1963; Klingenberg \& Froese, 1991; Klingenberg, 1996) was used for MAC calculation. The first principal component (PC1) corresponded to the "baseline of size variation" within a set of measurements (most of the variation in a multivariate data set). The coefficient (loading) of a given measurement on PC 1 divided by $1 / \sqrt{\mathrm{M}}$ (where $M$ is the number of measurements) is an allometric coefficient (according to Jolicoeur, 1963). In the model, MAC corresponds to the angle between PC1 and the measure and MAC values $>1.0$ indicate positive allometry, $\mathrm{MAC}=1.0$ indicates isometry, and $\mathrm{MAC}<1.0$ indicates negative allometry. MAC $=0$ indicates when variation in a given measure is completely independent of the general size of the skull (when there is no allometry). We used the bootstrap method (100 iterations for each sample) to estimate the means, standard errors, min and max values of MACs. To determine the variation among populations, we used MACs in PCA (Klingenberg \& Froese, 1991).

Table 2. Ontogenic multivariate allometric coefficients (MAC) in Eurasian beavers from three populations: $\mathrm{VO}, \mathrm{OK}$, and $\mathrm{CF}$.

\begin{tabular}{|l|c|c|c|c|c|c|c|c|c|}
\hline \multirow{2}{*}{$\begin{array}{c}\text { Measure- } \\
\text { ments }\end{array}$} & \multicolumn{3}{|c|}{ VO } & \multicolumn{3}{c|}{ OK } & \multicolumn{3}{c|}{ CF } \\
\cline { 2 - 10 } & MAC & min-max & Al. & MAC & min-max & Al. & MAC & min-max & Al. \\
\hline GL & $1.05 \pm 0.002$ & $1.00-1.12$ & $\sim$ & $1.00 \pm 0.001$ & $0.96-1.03$ & $\sim$ & $1.01 \pm 0.001$ & $0.98-1.04$ & $\sim$ \\
\hline NL & $1.18 \pm 0.004$ & $1.05-1.27$ & + & $1.30 \pm 0.003$ & $1.22-1.39$ & + & $1.29 \pm 0.002$ & $1.22-1.34$ & + \\
\hline UML & $1.15 \pm 0.007$ & $0.91-1.31$ & $\sim$ & $1.17 \pm 0.004$ & $1.05-1.27$ & + & $1.36 \pm 0.002$ & $1.31-1.40$ & + \\
\hline UDL & $0.66 \pm 0.006$ & $0.48-0.79$ & - & $0.82 \pm 0.003$ & $0.76-0.90$ & - & $0.96 \pm 0.002$ & $0.89-1.01$ & $\sim$ \\
\hline UJL & $1.33 \pm 0.005$ & $1.21-1.48$ & + & $1.16 \pm 0.003$ & $1.07-1.23$ & + & $1.14 \pm 0.003$ & $1.06-1.20$ & + \\
\hline UJW & $1.13 \pm 0.002$ & $1.08-1.19$ & + & $1.05 \pm 0.001$ & $1.01-1.08$ & $\sim$ & $0.31 \pm 0.009$ & $0.05-0.57$ & $-{ }^{\mathrm{a}}$ \\
\hline IOW & $0.74 \pm 0.006$ & $0.49-0.88$ & - & $0.93 \pm 0.004$ & $0.84-1.08$ & $\sim$ & $0.90 \pm 0.005$ & $0.80-1.03$ & $\sim$ \\
\hline ZW & $1.04 \pm 0.005$ & $0.91-1.12$ & $\sim$ & $1.08 \pm 0.002$ & $1.05-1.13$ & $\sim$ & $1.12 \pm 0.002$ & $1.08-1.16$ & + \\
\hline CW & $0.53 \pm 0.006$ & $0.43-0.77$ & - & $0.54 \pm 0.003$ & $0.44-0.60$ & - & $0.59 \pm 0.002$ & $0.54-0.65$ & - \\
\hline MW & $1.11 \pm 0.006$ & $0.97-1.26$ & $\sim$ & $1.10 \pm 0.003$ & $1.02-1.16$ & $\sim$ & $1.04 \pm 0.002$ & $1.00-1.08$ & $\sim$ \\
\hline DML & $0.64 \pm 0.007$ & $0.49-0.80$ & - & $0.61 \pm 0.002$ & $0.55-0.67$ & - & $0.61 \pm 0.002$ & $0.54-0.65$ & - \\
\hline GML & $1.06 \pm 0.003$ & $0.99-1.12$ & $\sim$ & $1.03 \pm 0.002$ & $0.98-1.08$ & $\sim$ & $1.02 \pm 0.002$ & $0.97-1.05$ & $\sim$ \\
\hline ML & $1.11 \pm 0.003$ & $1.02-1.18$ & + & $1.03 \pm 0.002$ & $0.98-1.07$ & $\sim$ & $1.03 \pm 0.001$ & $1.00-1.07$ & $\sim$ \\
\hline MH & $1.03 \pm 0.006$ & $0.83-1.19$ & $\sim$ & $1.07 \pm 0.002$ & $1.01-1.14$ & $\sim$ & $1.19 \pm 0.002$ & $1.12-1.22$ & + \\
\hline
\end{tabular}

Remarks: Al. — type of allometry: — close to isometry, - — negative allometry, + — positive allometry; ${ }^{\text {a }}$ — variation of the measure is close to independent from general size. 


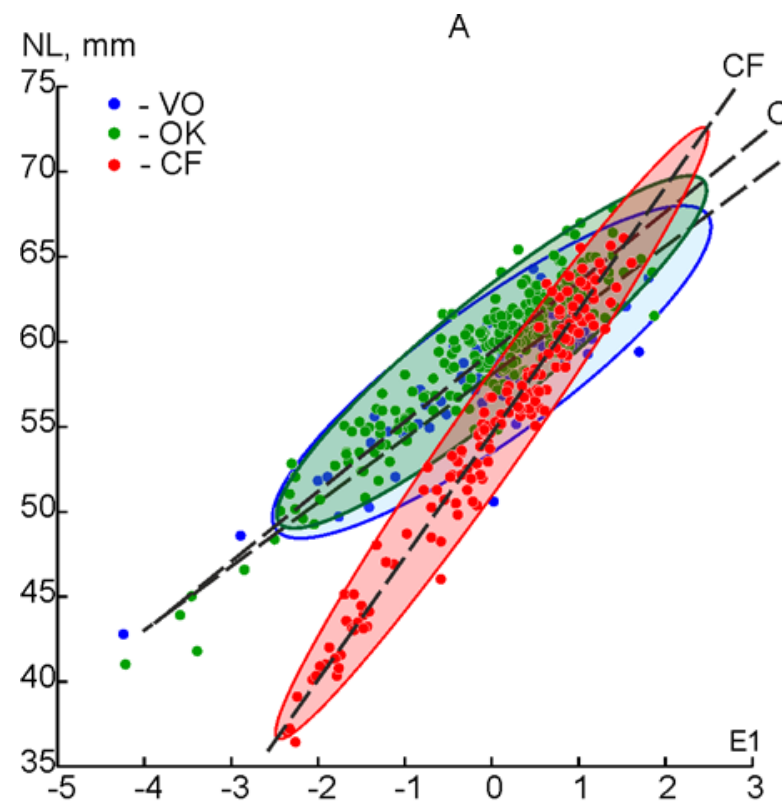

$$
\text { PC 2: } 8.9 \%
$$

B
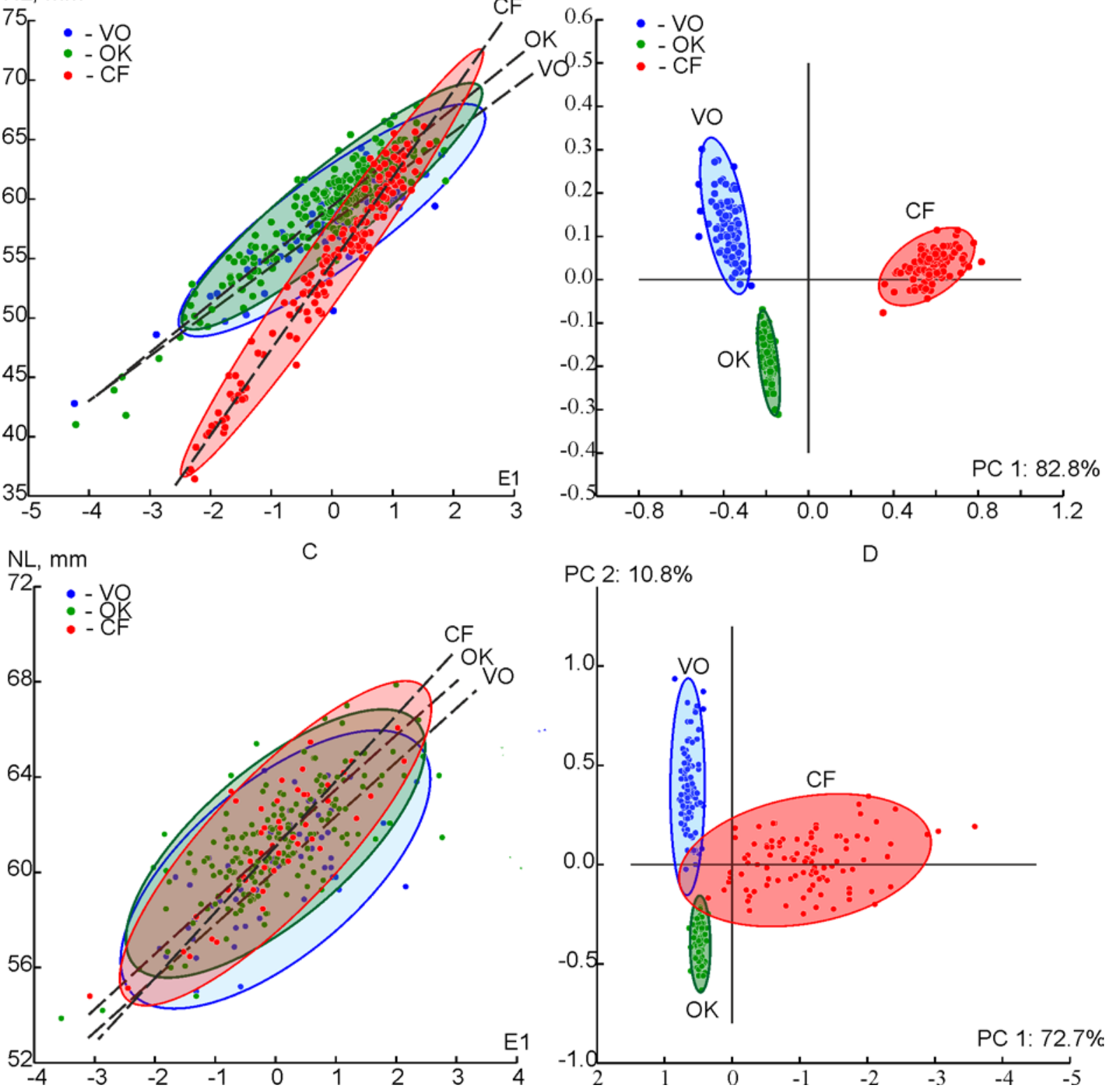

Figure 1. Allometric patterns in the populations VO, OK and CF: A, C - ontogenetic (A) and static (C) allometry of nasal length (NL); B, D - principal component analysis of MAC, ontogenetic allometric pattern (B) and static allometric pattern (D). PC 1 and PC 2 are the scores of MAC patterns of each beaver' population and 95\% confidence ellipses derived from the respective 100 bootstrap estimates of MACs are plotted.

\section{Results}

Ontogenetic Allometric Pattern. Ontogenetic allometry detected that the growth of general length of skull mainly depends on the increase of its rostral part (nasal bone, intermaxillae) (Table 2). The measurements RL and UDL exhibited a positive allometric trend in all populations. The measurements of skull length (CF, NL, and some others) had positive allometry, a possible effect of the continuous growth detected in reintroduced populations (Fig. 1). However, the expression of positive allometry was not great and very close to isometry in most cases. Negative allometry was expressed more clearly in the measurements IOW, CW, and DML in all populations and UML in the $\mathrm{VO}$ and $\mathrm{OK}$ populations. A specific property of the CF population is high variation in UJL where this measure increases independently from general skull size. According to the PCA results (Fig. 1), all three populations exhibited differences in their ontogenetic allometric patterns. The OK population was considerably closer in allometric pattern to the autochthonic 
Table 3. Static multivariate allometric coefficients (MAC) in adult Eurasian beavers from three populations: $\mathrm{VO}, \mathrm{OK}$, and $\mathrm{CF}$.

\begin{tabular}{|l|c|c|c|c|c|c|c|c|c|}
\hline \multirow{2}{*}{$\begin{array}{c}\text { Mea- } \\
\text { sure- } \\
\text { ments }\end{array}$} & \multicolumn{3}{|c|}{ VO } & \multicolumn{3}{c|}{ OK } & \multicolumn{3}{c|}{ CF } \\
\hline & MAC & min-max & Al. & MAC & min-max & Al. & MAC & min-max & Al. \\
\hline GL & $1.04 \pm 0.007$ & $0.88-1.17$ & $\sim$ & $0.94 \pm 0.003$ & $0.84-1.05$ & $\sim$ & $0.97 \pm 0.009$ & $0.64-1.33$ & $\sim$ \\
\hline NL & $1.31 \pm 0.011$ & $1.00-1.51$ & + & $1.50 \pm 0.007$ & $1.32-1.68$ & + & $1.38 \pm 0.01$ & $0.94-1.58$ & + \\
\hline UML & $0.92 \pm 0.016$ & $0.47-1.39$ & $\sim$ & $0.96 \pm 0.009$ & $0.75-1.15$ & $\sim$ & $1.26 \pm 0.01$ & $0.95-1.51$ & + \\
\hline UDL & $0.32 \pm 0.019$ & $0.22-0.72$ & $-^{\mathrm{a}}$ & $0.85 \pm 0.008$ & $0.66-1.07$ & - & $0.95 \pm 0.012$ & $0.54-1.32$ & $\sim$ \\
\hline UJL & $1.38 \pm 0.014$ & $0.98-1.76$ & + & $1.01 \pm 0.007$ & $0.81-1.22$ & $\sim$ & $1.14 \pm 0.018$ & $0.54-1.43$ & $\sim$ \\
\hline UJW & $1.06 \pm 0.012$ & $0.74-1.33$ & $\sim$ & $1.16 \pm 0.011$ & $0.84-1.43$ & $\sim$ & $0.59 \pm 0.035$ & $0.51-1.41$ & - \\
\hline IOW & $0.95 \pm 0.020$ & $0.53-1.53$ & $\sim$ & $0.92 \pm 0.011$ & $0.69-1.18$ & $\sim$ & $1.04 \pm 0.020$ & $0.41-1.50$ & $\sim$ \\
\hline ZW & $0.82 \pm 0.012$ & $0.49-1.13$ & $\sim$ & $1.04 \pm 0.005$ & $0.94-1.19$ & $\sim$ & $0.96 \pm 0.012$ & $0.43-1.19$ & $\sim$ \\
\hline CW & $0.61 \pm 0.012$ & $0.24-0.89$ & - & $0.67 \pm 0.007$ & $0.52-0.84$ & - & $0.63 \pm 0.010$ & $0.39-1.03$ & - \\
\hline MW & $1.09 \pm 0.01$ & $0.83-1.34$ & $\sim$ & $1.17 \pm 0.005$ & $1.04-1.31$ & + & $1.01 \pm 0.013$ & $0.39-1.25$ & $\sim$ \\
\hline DML & $0.66 \pm 0.016$ & $0.22-0.95$ & - & $0.65 \pm 0.007$ & $0.46-0.82$ & - & $0.78 \pm 0.010$ & $0.59-1.12$ & - \\
\hline GML & $1.04 \pm 0.006$ & $0.92-1.22$ & $\sim$ & $0.90 \pm 0.007$ & $0.72-1.02$ & $\sim$ & $0.85 \pm 0.017$ & $0.31-1.31$ & - \\
\hline ML & $1.07 \pm 0.006$ & $0.93-1.24$ & $\sim$ & $0.84 \pm 0.007$ & $0.61-1.07$ & - & $1.14 \pm 0.010$ & $0.67-1.37$ & $\sim$ \\
\hline MH & $0.97 \pm 0.011$ & $0.73-1.22$ & $\sim$ & $0.99 \pm 0.006$ & $0.82-1.15$ & $\sim$ & $0.95 \pm 0.012$ & $0.41-1.14$ & $\sim$ \\
\hline
\end{tabular}

Remarks: Al. — type of allometry: — close to isometry, - — negative allometry, + — positive allometry; ${ }^{\text {a }}$ — variation of the measure is close to independent from general size.

VO population than the second reintroduced population, $\mathrm{CF}$

Static Allometric Pattern. Static allometry was studied on adults in each population (growth stages ad1-ad4) and the static multivariate allometric patterns are characterized by a predominance of isometry (Table 3$)$. The rostrum length (RL) was associated with moderately high positive allometry in all populations. In the VO population, UDL showed positive allometry; in the CF population, NL showed positive allometry, and in the OK population, MW showed positive allometry (Fig. 1). However, the correlations between ontogenetic multivariate allometry coefficients and static multivariate allometry coefficients were relatively high, being 0.81 for the $\mathrm{CF}$ population, 0.78 for the $\mathrm{OK}$ population, and 0.86 for the $\mathrm{CF}$ population. Therefore, the three populations were well differentiated in the PC model space (Fig. 1D), but their allometric patterns were situated closer to each other.

\section{Discussion}

All three of the surveyed populations were genetically closely related (Horn et al., 2014). Such taxonomy is also supported by single nucleotide polymorphisms (SNPs) recently studied for autochthonous and reintroduced populations of $C$. fiber by Senn et al. (2014). The autochthonous VO population went through a bottleneck (less than 100 individuals) and has average values of genetic diversity relative to the other studied beaver populations (Senn et al., 2014). A small number of founders in reintroducing populations could lead to reduced genetic diversity. The rapid divergence in allometric patterns suggests that the founders of the reintroduced populations $\mathrm{OK}$ and $\mathrm{CF}$ either had genotypes that deviated by chance from the widespread genotypes in the VO population (founder effect), or that there was strong natural selection acting on the ontogeny within new habitats. If the first hypothesis is correct, we should observe a positive correlation between the number of founders and morphological similarity with the maternal population. Our results support this assumption: animals from the OK population (23 founders) had an allometric pattern that was closer to the VO population. The beavers from the CF population ( 8 founders) differed more from the parent population by allometry, morphological niche and some parameters of morphological diversity. To further test this hypothesis, it is necessary to investigate a much larger number of reintroduced populations of Eurasian beaver in Eastern Europe and Northern Asia.

The alternative hypothesis is that environmental, especially climatic, conditions influence the ontogenic process. Climate has been shown to have a complex impact on the morphological parameters of the skull in previous studies of Eurasian beavers (Korablev et al., 2011, 2015; Korablev \& Korablev, 2013). The climate of the Oka Reserve, in general, is closer to that of the 
Voronezh Reserve than to that of the Central Forest Reserve; thus, this hypothesis also does not contradict with the results of our study.

\section{Conclusion}

We are able to show significant differences (during postnatal ontogeny and in adult animals) between allometric patterns among autochthonous and reintroduced populations of Eurasian beavers. We conclude that allometry (ontogenetic and static) plays a certain role in morphological differentiation (disparity) between populations. All these results confirm our preliminary hypothesis, which was based on study of ontogeny, about the influence of ontogenetic allometry on the skull parameters in different beaver's populations (Puzachenko \& Korablev, 2014).

Our data support the contention that in beavers the divergence of phenotypes between parent and reintroduced populations developed during an extremely short interval, within a few decades (ecological time scale). Further examinations of the influence of the unique reintroduction experiment in Eastern Europe and Northern Asia on the morphological diversity of the Eurasian beaver may allow us to estimate the contribution of the genetic and epigenetic components to allometric diversity.

ACKNOWLEDGEMENTS. We express our gratitude to the curators of the Zoological Museum of the Moscow State University, Voronezh and Central Forest State Nature Biosphere Reserves for the access to scientific collections.

\section{References}

Cheverud J.M. 1996. Developmental integration and the evolution of pleiotropy // American Zoology. Vol.36. P.44-50.

Horn S., Prost S., Stiller M., Makowiecki D., Kuznetsova T., Benecke N., Pucher E., Hufthammer A.K., Schouwenburg Ch., Shapiro B. \& Hofreiter M. 2014. Ancient mitochondrial DNA and the genetic history of Eurasian beaver (Castor fiber) in Europe // Molecular Ecology. Vol.23. P.1717-1729.

Jolicoeur P. 1963. Note: The multivariate generalization of the allometry equation // Biometrics. Vol.9. No.3. P.497499.

Kitchener A.C. \& Lynch J.M. 2000. A morphometric comparison of the skulls of fossil British and extant European beavers, Castor fiber // Scottish Natural Heritage Review. Vol.127. P.1-31.

Klevezal G.A. 1988. [Recording Structures of Mammals in Zoological Research]. Moscow: Nauka. 142 p. [in Russian].

Klingenberg C.P. 1996. Multivariate allometry // Marcus L.F., Corti M., Loy A., Naylor G.J.P. \& Slice D.E. (eds.). Advances in Morphometrics. New York: Plenum Press. P.23-49.
Klingenberg C.P. 2014. Studying morphological integration and modularity at multiple levels: concepts and analysis // Philosophical Transactions of the Royal Society, Series B. Vol.369: 20130249. doi: 10.1098/rstb.2013.0249.

Klingenberg C.P. \& Froese R. 1991. A multivariate comparison of allometric growth patterns // Systematic Zoology. Vol.40. No.4. P.410-419.

Klingenberg C.P., Leamy L.J. \& Cheverud J.M. 2004. Integration and modularity of quantitative trait locus effects on geometric shape in the mouse mandible // Genetics. Vol.166. P.1909-1921.

Klingenberg C.P. \& Zimmermann M. 1992. Static, ontogenetic, and evolutionary allometry: a multivariate comparison in nine species of water striders // The American Naturalist. Vol.140. P.601-620.

Korablev N., Puzachenko Y., Zavyalov N. \& Zheltukhin A. 2011. Long-term dynamics and morphological peculiarities of reintroduced beaver population in the Upper Volga Basin // Baltic Forestry. Vol.17. No.1. P.136-147.

Korablev N.P. \& Korablev P.N. 2013. Patterns of morphological variability in reintroduced populations with two beaver subspecies Castor fiber orientoeuropaeus and Castor fiber belorussicus (Castoridae, Rodentia) as an example // Biology Bulletin Reviews. Vol.3. No.1. P.8497.

Korablev N.P., Saveljev A.P. \& Puzachenko Yu.G. 2015. [Factors of polymorphism in autochthonous and reintroduced of Eurasian beavers (Castor fiber, Castoridae, Rodentia)] // Zoologicheskii Zhurnal. Vol.94. No.2. P.241-258 [in Russian with English summary].

Lavrov L.S. 1981. [Beavers of Palearctic]. Voronezh: Voronezh State University. 270 p. [in Russian].

Olson E. \& Miller R. 1958. Morphological Integration. Chicago: University of Chicago Press. 376 p.

Pankova N.L. \& Pankov A.B. 2011. [The history of the formation and current status of beaver populations on the territory of the Oka Reserve] // Abstracts of Papers, IX Congress of Theriological Society of the RAS. Moscow: KMK Scientific Press. P.362 [in Russian].

Puzachenko A.Yu. \& Korablev N.P. 2014. Morphological diversity in the postnatal skull development in representatives of two families of rodents (Spalacidae, Castoridae, Rodentia) // Russian Journal of Developmental Biology. Vol.45. No.3. P.149-162.

Romer A.S. \& Parsons T.S. 1985. The Vertebrate Body. Sixth edition. Philadelphia: Saunders. 679 p.

Safonov V.G. 1966. [Morphological features and structure of beaver populations] // Byulleten' Moskovskogo Obshchestva Ispytatelei Prirody, Otdel Biologicheskii. No.4. P.5-19 [in Russian with English summary].

Senn H., Ogden R., Frosch Ch., Syrçèková A., CampbellPalmer R., Munclinger P., Durka W., Kraus R.H.S., Saveljev A.P., Nowak C., Stubbe A., Stubbe M., Michaux J., Lavrov V., Samiya R., Ulevicius A. \& Rosell F. 2014. Nuclear and mitochondrial genetic structure in the Eurasian beaver (Castor fiber) - implications for future reintroductions // Evolutionary Applications. Vol.7. P.645-662.

Trainor P.A., Melton K.R. \& Manzanares M. 2003. Origins and plasticity of neural crest cells and their roles in jaw and craniofacial evolution // International Journal of Developmental Biology. Vol.47. P.541-553. 